\title{
Removal of Heavy Metals and Nutrients from Municipal Wastewater using Salvinia molesta and Lemna gibba
}

\author{
M.L.D.D. Abhayawardhana ${ }^{1 *}$, N.J.G.J. Bandara ${ }^{1}$ and S.K.L.S. Rupasinghe ${ }^{2}$ \\ ${ }^{I}$ Department of Forestry and Environmental Science, University of Sri Jayewardenepura, Sri Lanka \\ ${ }^{2}$ National Water Supply and Drainage Board, Ratmalana
}

Date Received: 26-03-2019

Date Accepted: 12-12-2019

\begin{abstract}
The present study was focused on the investigation of the abilities and efficiencies of Salvinia molesta and Lemna gibba to remove selected heavy metals $(\mathrm{Cr}, \mathrm{Cu}, \mathrm{Fe}, \mathrm{Ni}$ and $\mathrm{Pb})$ and excess nutrients from wastewater taken from the Moratuwa-Ratmalana municipal wastewater treatment plant. The wastewater samples were analysed for $\mathrm{pH}$, Temperature, for N-Nitrates, N-Nitrites, ammonia Nitrogen, Phosphates, and selected heavy metals, Biochemical Oxygen Demand (BOD), Chemical Oxygen Demand (COD) and Total Kjeldhal Nitrogen. Then, the wastewater samples were treated with $S$. molesta and $L$. gibba separately for a period of 7 days and analysed for N-Nitrates, N-Nitrites, Ammonia Nitrogen, Phosphates and five selected heavy metals at 24 hour intervals. BOD, COD and Total Kjeldhal Nitrogen were analysed at 7 days intervals. The average Total Nitrogen removal efficiencies of $S$. molesta and $L$. gibba were $73.3 \%$ and $62.1 \%$ whereas the average Total Phosphate removal efficiencies of S. molesta and L. gibba were $72.6 \%$ and $77.2 \%$ respectively. The average $\mathrm{Cr}, \mathrm{Cu}, \mathrm{Fe}, \mathrm{Ni}$ and $\mathrm{Pb}$ removal efficiencies of S. molesta were $81.6 \%, 69.8 \%, 65.2 \%, 66.3 \%$ and $74.8 \%$ respectively. The average $\mathrm{Cr}, \mathrm{Cu}, \mathrm{Fe}, \mathrm{Ni}$ and $\mathrm{Pb}$ removal efficiencies shown by $L$. gibba were $86.9 \%, 69.7 \%, 73.1 \%, 61.8 \%$ and $85.7 \%$ respectively. The Bio Concentration factors of $S$. molesta for $\mathrm{Cr}, \mathrm{Cu}, \mathrm{Fe}, \mathrm{Pb}$ and $\mathrm{Ni}$ were 823, 698, 652, 663 and 748 respectively and the Bio Concentration factors of $S$. molesta for $\mathrm{Cr}, \mathrm{Cu}, \mathrm{Fe}, \mathrm{Pb}$ and $\mathrm{Ni}$ were 870, 698, 731, 618 and 857 respectively. According to the obtained results in the present study S. molesta and L. gibba can be considered as suitable candidates for the polishing of municipal wastewater.
\end{abstract}

Keywords: Heavy metals, Lemna gibba, nutrients, Salvinia molesta

\section{Introduction}

Wastewater contains Biodegradable organics, Nutrients; mainly nitrogen and phosphate compounds that lead to eutrophication, Organic pollutants, heavy metals and dissolved inorganics such as sodium, calcium and sulphates etc. Almost all the human activities generate wastewater. Nature has an assimilation capacity to cope with small amounts of wastewater and pollution associated with it, but nature has no capacity to handle the huge amount of wastewater that is generated every day after being subjected to human consumption and several other uses. Therefore, the treatment of this water and returning clean and safe water into the waterways is essential to ensure the safety of people and the environment. The proper treatment of wastewater is an environmental challenge since the wastewater is required to be treated and disposed safely in an efficient manner. Further, the presence of some components in the water poses a challenge in the wastewater treatment process.

*Correspondence: dnudilini@ gmail.com

ISSN 2235-9370 Print/ISSN 2235-9362 Online @ University of Sri Jayewardenepura 
Enrichment of large quantities of nitrogen and phosphate compounds in wastewater is one of the main causes of eutrophication that negatively affects many natural water bodies. Heavy metals are considered as priority pollutants due to their acute toxicity. Heavy metals in wastewater cause detrimental effects on environment and human health. The heavy metals in wastewater have the potential of bioaccumulation which can cause adverse impacts on environment and human health.

Phytoremediation is the use of both aquatic and terrestrial plants for the treatment of contaminated water and soils (Ali et al., 2013). According to previous studies, some aquatic macrophytes have shown a great promise in wastewater treatment, both in the removal of nutrients (Phosphates, Nitrogen compounds) and heavy metals. S. molesta and L. gibba are two preferable candidates which had been used for the treatment of wastewater in previous studies. Low cost and easy maintenance make the aquatic plant system preferable to use. In an aqueous solution, metals are available in soluble form. Therefore, the accumulation by the aquatic plants can be achieved much more easily and more efficiently than using terrestrial plants.

S. molesta is a free floating aquatic plant which spreads rapidly by vegetative reproduction. The species is well-known for its phytoremediation potential (Koutika and Rainey, 2015). L. gibba is a rooted free-floating aquatic plant consisting of small fronds. Due to the high growth rate and large potential for the uptake of heavy metals and nutrients, members of Genus Lemna have appeared as suitable candidates for the phytoremediation of heavy metal contaminated wastewater (Verma and Suthar, 2015).

According to previous studies, the influent of Moratuwa-Ratmalana wastewater treatment plant contains Total nitrogen and total phosphates higher than the upper limits given in the standards. The presence of several heavy metals i.e. $\mathrm{Cu}, \mathrm{Cr}, \mathrm{Pb}, \mathrm{Fe}$, and $\mathrm{Ni}$ is also recorded (Danushika et al., 2017). Since the sludge disposed by the treatment plant constitutes of heavy metals, the final disposal of sludge has posed problematic issues. The study is carried out to determine the efficiency of $S$. molesta and L. gibba as candidates for polishing of the influent of Moratuwa-Ratmalana wastewater treatment plant. The potential of using S. molesta and L. gibba for the removal of nutrients (nitrogen compounds, phosphates) and selected heavy metals $(\mathrm{Cr}, \mathrm{Cu}, \mathrm{Ni}, \mathrm{Pb}, \mathrm{Fe})$ is determined in the study, thus investigating the capability of these two aquatic macrophytes to be used for the treatment of municipal wastewater.

\section{Methodology}

\subsection{Plant acquisition and acclimatisation}

S. molesta was collected from a fresh water body near the University. L. gibba was collected from Moratuwa-Ratmalana wastewater treatment plant. Healthy mature plants were selected for the experiment and rinsed with tap water in order to remove adhering mud particles or epiphytes. The plants were left for an adaptation period of 10 days, growing in the containers inside the Green house of Department of Forestry and Environmental Science, University of Sri Jayewardenepura to be adapted for the experimental conditions.

\subsection{Sample collection}

Wastewater samples were collected from the inlet of the Moratuwa-Ratmalana wastewater treatment plant. Samples were collected weekly. After the collection, the samples were checked for $\mathrm{pH}$, Temperature, Biochemical Oxygen Demand (BOD), Chemical Oxygen Demand (COD), Nitrates, Nitrites, Ammonia Nitrogen, Phosphates and Total Kjeldhal Nitrogen and heavy metals $(\mathrm{Cr}, \mathrm{Cd}, \mathrm{Cu}, \mathrm{Mn}, \mathrm{Pb}, \mathrm{Ni}$, and $\mathrm{Fe}$ ).

The $\mathrm{pH}$ was measured using the $\mathrm{pH}$ meter and the temperature was measured using a thermometer at the time of sample collection. BOD was measured using Winkler method. COD was determined using closed reflux method. Ammonia Nitrogen was measured by comparative Ammonia method. Total Kjeldhal Nitrogen concentration was measured by Micro Kjeldhal method. The concentrations of Nitrates, Nitrites and Phosphates were measured using HACH 890 meter by Powder Pillow method. The 
concentrations of the heavy metals were measured by Atomic Absorption Spectroscopy (AAS) method. The wastewater samples were collected in polypropylene bottles and were transferred to the green house immediately.

\subsection{Experimental design}

Eight rectangular shaped glass aquariums with the dimensions of $11^{\prime} \times 6 " \times 6$ " were used to perform the experiment. Six containers were taken and 31 of collected wastewater was added to each tank. To three tanks, $15 \mathrm{~g}$ of $S$. molesta was introduced. To other three tanks, $15 \mathrm{~g}$ of $L$. gibba was introduced. The other two tanks were filled with distilled water. $15 \mathrm{~g}$ of $S$. molesta was added to one tank and $15 \mathrm{~g}$ of L. gibba was added to the other tank. These two tanks with distilled water were used as control samples in order to compare the relative growth of the plants in wastewater and the control samples. Each experiment was carried out for 7 days. $40 \mathrm{ml}$ of wastewater samples were withdrawn from each tank at 24 hour intervals. The seven day experiment was repeated for six times.

\subsection{Sample analysis}

The samples withdrawn from the tanks at 24 hour intervals were checked for $\mathrm{pH}$, temperature, nitrates, nitrites, ammonia nitrogen and phosphates. The collected water samples were filtered using Whatmann No.1 filter papers and were analysed using atomic absorption spectroscopy (AAS) method to determine $\mathrm{Cr}, \mathrm{Cu}, \mathrm{Pb}, \mathrm{Ni}$ and $\mathrm{Fe}$ concentrations at 24 hour intervals. At the end of the experiment, on the $7^{\text {th }}$ day, the samples were checked for BOD, COD and total Kjeldhal nitrogen.

\subsection{Analysis of plant materials}

On the $7^{\text {th }}$ day, plant materials were harvested and their fresh weights were determined. Then the plant materials were oven dried at $800^{\circ} \mathrm{C}$ for 48 hours and the dry weights were determined. Then the dried biomass was digested according to dry digestion method (Kalagbor and Opusunju, 2015) and were analysed for concentrations of $\mathrm{Cr}, \mathrm{Cu}, \mathrm{Pb}, \mathrm{Ni}$, and $\mathrm{Fe}$ using Atomic Absorption Spectroscopy.

\subsection{Calculations}

The following parameters were calculated using the mean values of the data obtained through the experiments.

\section{Relative growth}

Relative growth values were calculated for S. molesta and L. gibba using the initial fresh weight and final fresh weight values.

Relative growth $=\frac{\text { Final fresh weight }(\mathrm{g})}{\text { Initial fresh weight }(\mathrm{g})}$

(Thayaparan et al., 2013)

Removal efficiency

The removal efficiencies for total Nitrogen, total Phosphates, COD, BOD and selected heavy metals by $S$. molesta and L. gibba were calculated using initial and final values.

Removal efficiency $=\frac{\text { Initial concentration }- \text { Final concentration }}{\text { Initial concentration }} \times 100$

\section{Metal uptake capacity}

The uptake capacities for each metal for S. molesta and L. gibba were calculated.

Metal uptake capacity $(\mathrm{mg} / \mathrm{kg})=\frac{\text { Metal concentration of the dried biomass }\left(\frac{\mathrm{mg}}{1}\right) \times \text { Total diluted volume }(\mathrm{ml})}{\text { Dry weight }(\mathrm{g})}$ 


\section{Bio Concentration Factor (BCF)}

The Bio Concentration Factors for each metal for S. molesta and L. gibba were calculated.

$\mathrm{BCF}=\frac{\text { Metal concentration of the dried biomass }\left(\frac{\mathrm{mg}}{\mathrm{kg}}\right)}{\text { Initial concentration of the metal in external solution }\left(\frac{\mathrm{mg}}{1}\right)}$

\subsection{Statistical Analysis}

(Uysal, 2013)

The data were statistically analysed using Minitab 18 software. The significant differences among the parameters were determined by One-way Anova test. The treatment means were compared using Tukey's 95\% simultaneous confidence intervals test.

\section{Results and Discussion}

\subsection{Nutrient removal by S. molesta and L. gibba}

Total nitrogen

In the present study, the final total nitrogen concentrations in the tanks with S. molesta and $L$. gibba were $31.82 \mathrm{mg} \mathrm{l}^{-1}$ and $51.81 \mathrm{mg} \mathrm{l}^{-1}$ respectively, whereas the initial Total Nitrogen concentration was $136.27 \mathrm{mg} \mathrm{l}^{-1}$ S. molesta showed a significantly higher potential $(\mathrm{p}<0.05)$ in the uptake of total nitrogen than $L$. gibba in the present study.

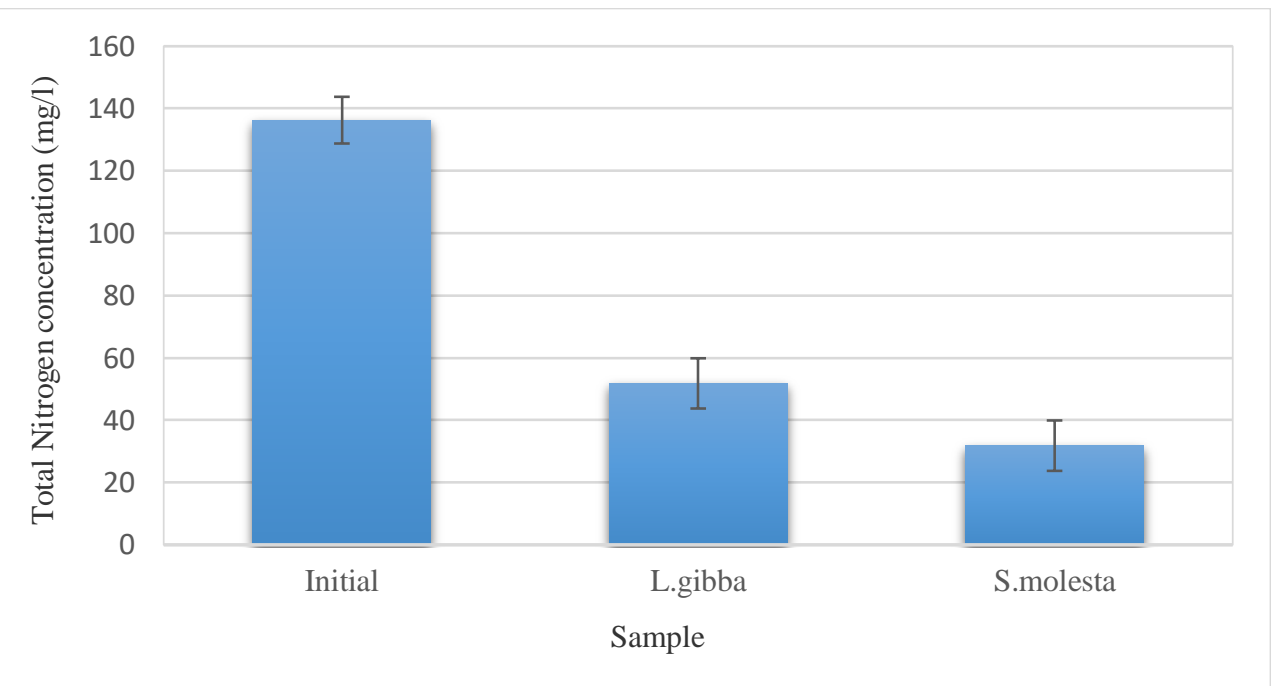

Figure 1. The mean values of initial and final concentrations of Total Nitrogen in the tank with $S$. molesta and in the tank with L. gibba. Bars indicate mean \pm SD (Standard Deviation), where $\mathrm{n}=6$.

According to $\mathrm{Ng}$ and Chan (2017), the nitrate concentration in palm oil mill effluent treated by $S$. molesta has increased until day 12 and then has slightly decreased in the end. In a free floating system, the total nitrate concentration is controlled by nitrification and denitrification, in addition to plant and microbial uptake. In the present study also, the nitrate concentration of the tank with S. molesta had remained constant from day 3 to day 4 . The nitrate concentration in L. gibba had increased slightly from day 3 to day 4 . These are due to the increase of nitrates as a result of nitrification. However, in the present study, the increase of nitrates by nitrification is not much high. nitrification/ denitrification can be caused by nitrifying bacteria which are attached to flocculates (Korner and Vermaat, 1998). But, the flocculates settled to the bottom of the tanks due to the small depth of the tanks. Therefore, the nitrification/ denitrification by suspended bacteria can be neglected. 
In the present study, volatilisation of ammonium ions as ammonia gas can be neglected since the surface of the tank is covered with the dense mat of plant materials. Also, the $\mathrm{pH}$ value of the wastewater had remained close to neutral values throughout the experiment. Therefore, only a small amount of ammonium ion may be present as ammonia gas.

The concentrations of nitrites, nitrates, ammonia nitrogen and phosphates in the tank with $S$. molesta had decreased daily in the seven day period. The total nitrate concentration did not show a gradual decrease. The concentration of nitrates had remained constant from day 3 to day 4. The concentrations of nitrites, nitrates, ammonia nitrogen and phosphates in the tank with L. gibba had decreased in the period of 7 days. The concentration of nitrates has shown a slight increase from day 3 to day 4.

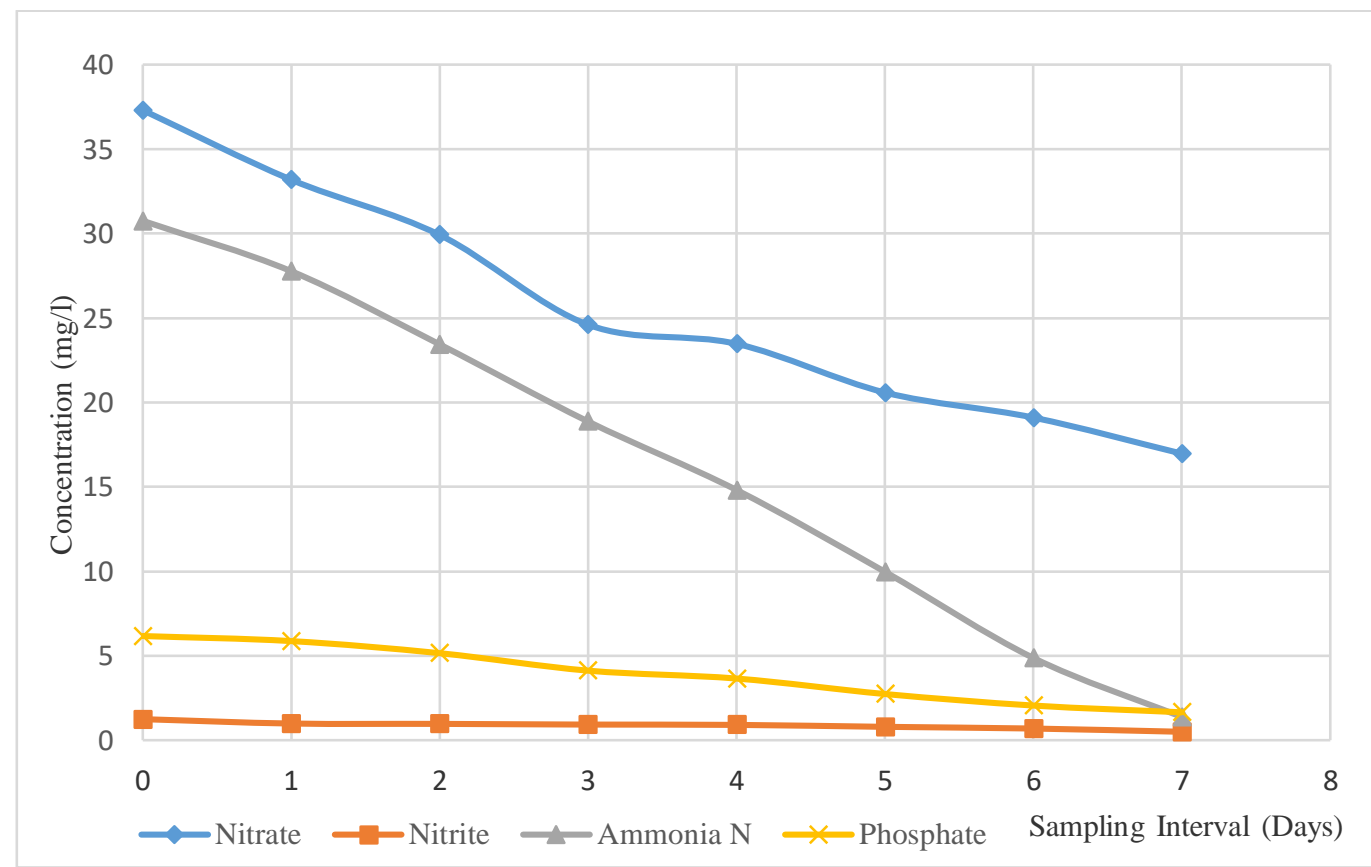

Figure 2. The daily variation of the mean values of concentrations of nitrites, nitrates, ammonia nitrogen and phosphates in the tank with S.molesta where $\mathrm{n}=6$.

The total nitrogen removal efficiencies of S. molesta and L. gibba were $73.35 \%$ and $62.18 \%$ respectively. S. molesta has shown a significantly greater $(\mathrm{p}<0.05)$ efficiency in the removal of Total Nitrogen than L. gibba. According to Žaltauskaitè et al., (2014), the efficiency of L. gibba in the removal of Nitrogen from wastewater is between $42 \%-62 \%$ of total nitrogen, depending on initial nitrogen concentrations. The present study has also shown similar results. According to Mkandawire and Dudel, (2005), the total Nitrogen removal efficiency by Lemna spp. is 50\%. In the present study, L. gibba has demonstrated an efficiency higher than that.

\subsubsection{Total phosphate}

Phosphorous is an essential macronutrient for plants which is required for the synthesis of Adenosine Diphosphate (ADP), Adenosine Triphosphate (ATP) and nucleic acids. Therefore, free orthophosphates are specifically absorbed from wastewater by plant systems. In the present study, the initial concentrations of Total Phosphates in the tanks with S. molesta and L. gibba were $1.65 \mathrm{mg}^{-1}$ and $1.5 \mathrm{mg} \mathrm{l}^{-1}$ respectively, whereas the initial concentration was $6.17 \mathrm{mg} / 1$. The final Total Phosphate concentrations in the two tanks were not significantly different $(p>0.05)$. 


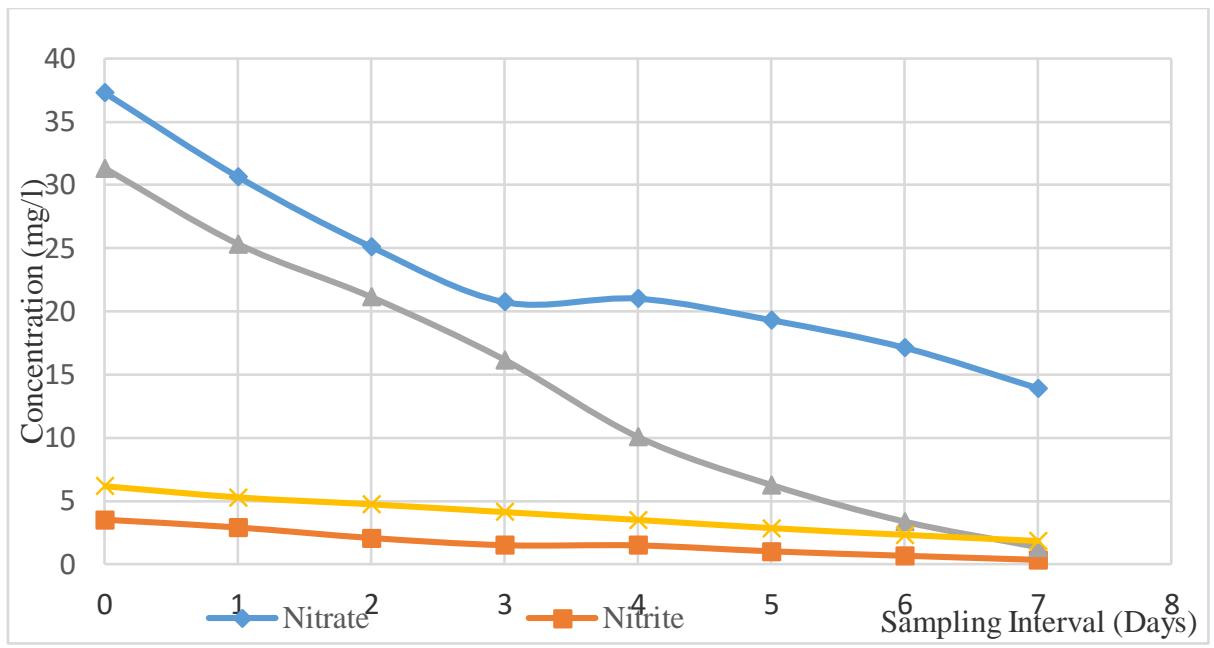

Figure 3. The daily variation of the mean values of concentrations of nitrites, nitrates, ammonia nitrogen and phosphates in the tank with L. gibba where $\mathrm{n}=6$.

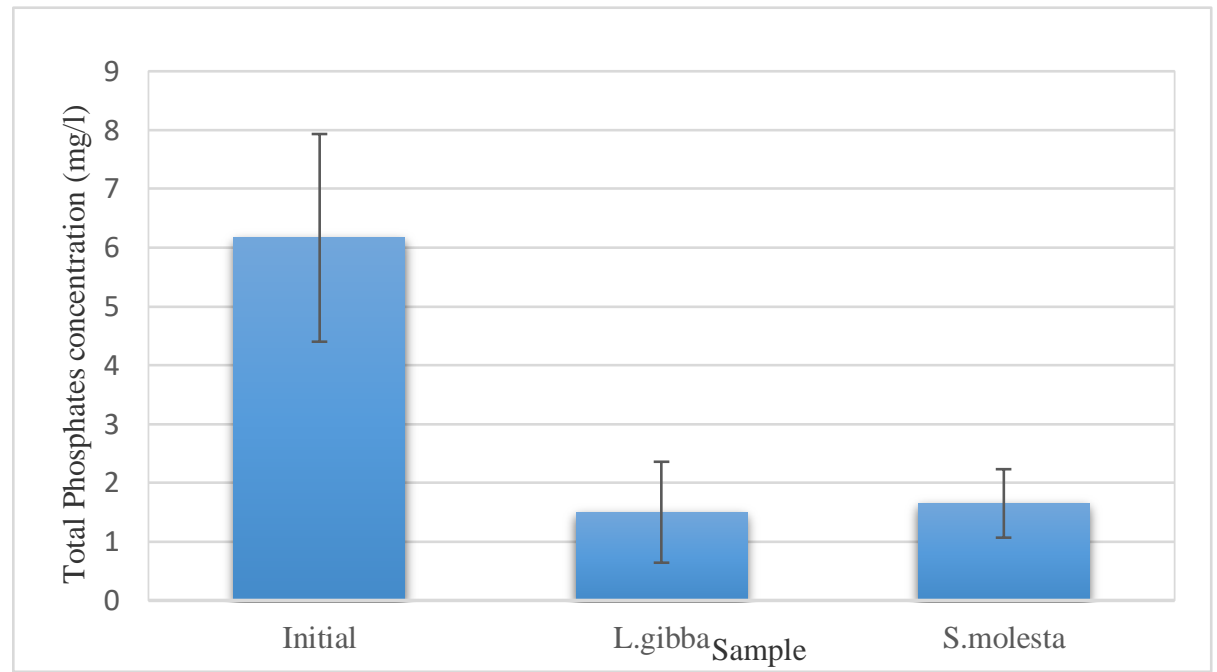

Figure 4. The mean values of initial and final concentrations of total phosphate in the tank with $S$. molesta and in the tank with L. gibba. Bars indicate mean \pm SD, where $\mathrm{n}=6$.

Mohedano et al., (2012) showed a final total phosphate concentration of $5.2 \mathrm{mg} \mathrm{l}^{-1}$ on day seven, whereas the initial concentration was $215 \mathrm{mg} \mathrm{l}^{-1}$ in which the swine waste was treated by L. gibba. In this study, the effluent has been sent through a system consisting of a storage pond and two duckweed ponds. Therefore, the removal potential is higher than the present study as the effluent has gone through the Duckweed pond twice in a single treatment and because of the increased surface area for the treatment.

The total Phosphate removal efficiencies of S. molesta and L. gibba were $72.63 \%$ and $77.29 \%$ respectively which were not significantly different $(\mathrm{p}>0.05)$. According to Žaltauskaite et al., (2014), the total phosphate removal efficiency from municipal wastewater by L. minor is $100 \%$. However, Mkandawire and Dudel, (2005) shows that the efficiency of Total Phosphate removal by Lemna spp. is between 50-60\%. In the present study, L. gibba has demonstrated a greater efficiency than that.

$B O D$ and $C O D$

The mean initial BOD value was $259.22 \mathrm{mg} \mathrm{l}^{-1}$ whereas the mean final BOD values in the tank with $S$. molesta and in the tank with $L$. gibba were $73.75 \mathrm{mg} \mathrm{l}^{-1}$ and $85.29 \mathrm{mg} \mathrm{l}^{-1}$ respectively which were not significantly different ( $p>0.05$ ). The mean initial COD value was $530.19 \mathrm{mg} / \mathrm{l}$ whereas the mean final 
COD values in the tank with $S$. molesta and in the tank with $L$. gibba were $200.80 \mathrm{mg} \mathrm{l}^{-1}$ and $111.89 \mathrm{mg} \mathrm{l}^{-}$ ${ }^{1}$ respectively which were significantly different $(\mathrm{p}<0.05)$. The COD reduction potential demonstrated by L. gibba was higher than in that of $S$. molesta in the present study. In the present study, the BOD removal efficiencies of S. molesta and L. gibba were $71.51 \%$ and $67.24 \%$ respectively which were not significantly different ( $>0.05)$. The COD removal efficiencies of S. molesta and L. gibba were $61.985 \%$ and $78.957 \%$ respectively. L.gibba demonstrated a significantly higher efficiency $(\mathrm{p}<0.05)$ in the removal of COD.

According to Mkandawire and Dudel (2005), the BOD removal efficiency and COD removal efficiency of Lemna spp. are 60\% and 30-40\% respectively. But, in the present study, L. gibba has shown greater efficiencies than that in the removal of both BOD and COD. Kumari and Tripathi (2014) reports BOD and COD removal efficiencies by mixed culture of Eichhornia crassipes and Salvinia natans accompanied by aeration in municipal wastewater as $84.5 \%$ and $83.2 \%$ respectively. The efficiencies are greater than the BOD and COD removal efficiencies of S. molesta and L. gibba recorded in the present study. The effect of aeration and the enhancement of removal caused by the use of mixed culture of Eichhornia crassipes and Salvinia natans can be the reasons for higher efficiencies.

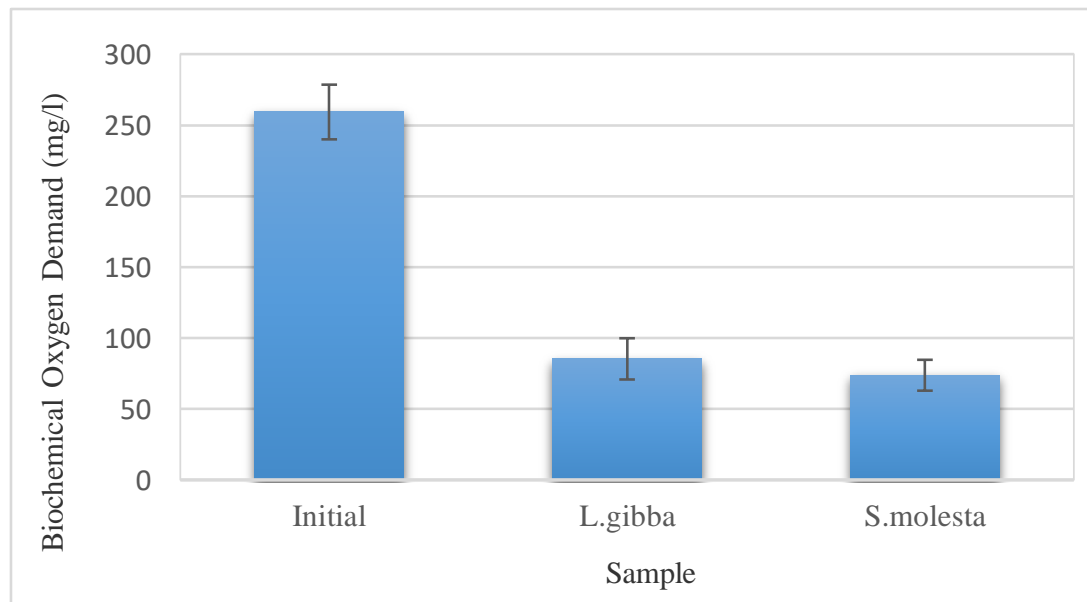

Figure 5. The mean values of initial and final values of BOD in the tank with $S$. molesta and in the tank with L. gibba. Bars indicate mean $\pm \mathrm{SD}$, where $\mathrm{n}=6$.

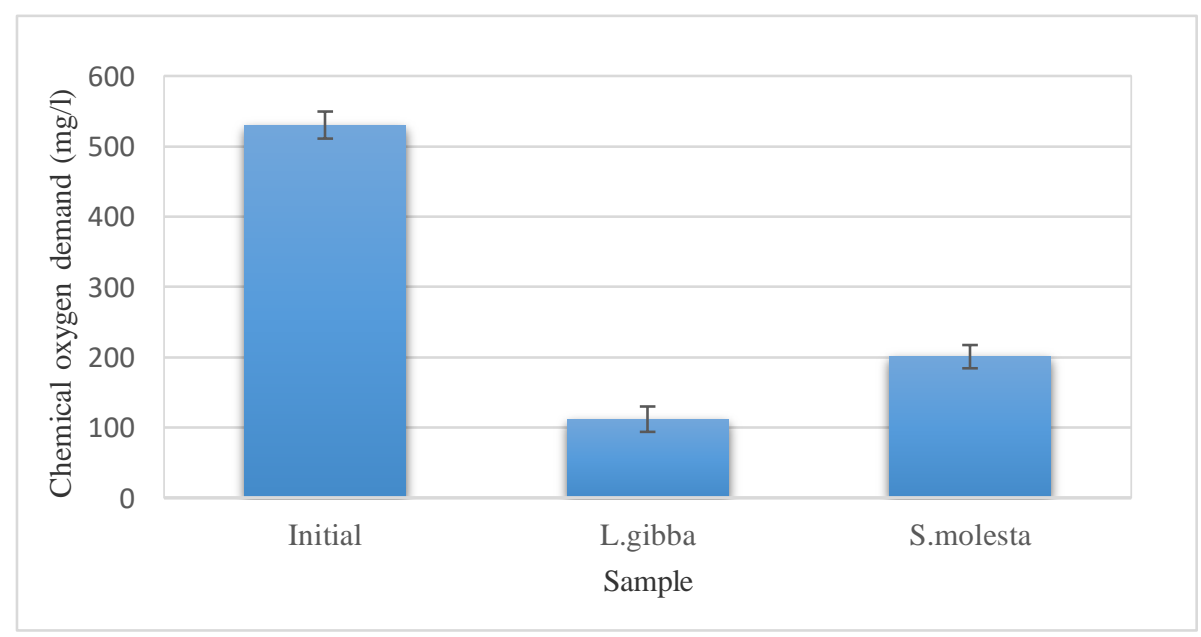

Figure 6. The mean values of initial and final values of COD in the tanks with S. molesta and L. gibba. Bars indicate mean $\pm \mathrm{SD}$, where $\mathrm{n}=6$. 


\subsection{Heavy metal removal by Salvinia molesta and Lemna gibba \\ Chromium (Cr)}

The final $\mathrm{Cr}$ concentrations of the two tanks were not significantly different $(\mathrm{p}>0.05)$. The $\mathrm{Cr}$ uptake capacity of $L$. gibba was significantly greater $(\mathrm{p}<0.05)$ than that of $S$. molesta. The Bio Concentration Factor (BCF) of S. molesta and L. gibba were not significantly different ( $\mathrm{p}>0.05$ ) and both were lower than 1,000 . The initial $\mathrm{Cr}$ concentration was higher than tolerance limits for industrial and domestic wastewater discharged into marine coastal areas $\left(1 \mathrm{mg} \mathrm{l}^{-1}\right)$. The final concentrations of $\mathrm{Cr}$ in both tanks were lower than the tolerance limit. But, toxicity symptoms were not observed in the harvested plant materials.

Table 1: The mean values of initial $\mathrm{Cr}$ concentration in wastewater samples, final $\mathrm{Cr}$ concentration after being subjected to the treatment by plants, the metal uptake capacities of the two species and the Bio Concentration Factors (BCF).

\begin{tabular}{lcccc}
\hline Characteristic & $\begin{array}{c}\text { Control } \\
\text { Salvinia molesta }\end{array}$ & $\begin{array}{c}\text { Control } \\
\text { Lemna gibba }\end{array}$ & Salvinia molesta & Lemna gibba \\
\hline $\begin{array}{l}\text { Initial concentration } \\
\left(\mathrm{mg} \mathrm{l}^{-1}\right)\end{array}$ & - & - & $1.58 \pm 0.08^{\mathrm{A} 1}$ & $1.58 \pm 0.08^{\mathrm{A} 1}$ \\
$\begin{array}{l}\text { Final concentration } \\
\left(\mathrm{mg} \mathrm{l}^{-1}\right)\end{array}$ & - & - & $0.29 \pm 0.07^{\mathrm{B} 1}$ & $0.21 \pm 0.05^{\mathrm{B} 1}$ \\
$\begin{array}{l}\text { Metal uptake capacity } \\
\left(\mathrm{mg} \mathrm{kg}^{-1}\right)\end{array}$ & - & - & $64.32 \pm 2.44^{\mathrm{B} 2}$ & $68.55 \pm 2.64^{\mathrm{A} 2}$ \\
$\mathrm{BCF}$ & - & - & $823.2 \pm 40.78^{\mathrm{A} 3}$ & $870.0 \pm 28.25^{\mathrm{A} 3}$ \\
\hline
\end{tabular}

The significant differences are indicated by superscripted letters.

The Cr removal efficiencies of S. molesta and $L$. gibba are $81.66 \%$ and $86.99 \%$ respectively, which were significantly different $(\mathrm{p}<0.05)$. L. gibba demonstrated a higher $\mathrm{Cr}$ removal efficiency than $S$. molesta in the present study.

Copper $(\mathrm{Cu})$

The final $\mathrm{Cu}$ concentrations of the two tanks were not significantly different $(\mathrm{p}>0.05)$. In addition, the $\mathrm{Cu}$ uptake capacities of S. molesta and L. gibba were not significantly different (p>0.05). The $\mathrm{BCF}$ values of the two plants for $\mathrm{Cu}$ were not significantly different $(\mathrm{p}>0.05)$ and the values were lower than 1000 .

The Cu removal efficiencies of S.molesta and L.gibba were $69.81 \%$ and $69.78 \%$ respectively. The efficiencies were not significantly different $(\mathrm{p}>0.05)$.

Table 2: The mean values of initial $\mathrm{Cu}$ concentration in wastewater samples, final $\mathrm{Cu}$ concentration after being subjected to the treatment by plants, the metal uptake capacities of the two species and the Bio Concentration Factors (BCF).

\begin{tabular}{|c|c|c|c|c|}
\hline Characteristic & $\begin{array}{c}\text { Control } \\
\text { Salvinia molesta } \\
\end{array}$ & $\begin{array}{c}\text { Control } \\
\text { Lemna gibba }\end{array}$ & Salvinia molesta & Lemna gibba \\
\hline $\begin{array}{l}\text { Initial concentration } \\
\left(\mathrm{mg} \mathrm{l}^{-1}\right)\end{array}$ & - & 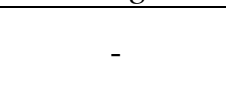 & $0.302 \pm 0.13^{\mathrm{A} 1}$ & $0.302 \pm 0.13^{\mathrm{A} 1}$ \\
\hline $\begin{array}{l}\text { Final concentration } \\
\left(\mathrm{mg} \mathrm{l}^{-1}\right)\end{array}$ & - & - & $0.097 \pm 0.07^{\mathrm{B} 1}$ & $0.094 \pm 0.05^{\mathrm{B} 1}$ \\
\hline $\begin{array}{l}\text { Metal uptake capacity } \\
\left(\mathrm{mg} \mathrm{kg}^{-1}\right)\end{array}$ & - & - & $10.283 \pm 3.78^{\mathrm{A} 2}$ & $10.408 \pm 4.14^{\mathrm{A} 2}$ \\
\hline $\mathrm{BCF}$ & - & - & $698.029 \pm 72.86^{\mathrm{A3}}$ & $698.421 \pm 64.80^{\mathrm{A} 3}$ \\
\hline
\end{tabular}

The significant differences are indicated by superscripted letters.

Iron $(\mathrm{Fe})$ 
The final Fe concentrations of the two tanks were not significantly different ( $\mathrm{p}>0.05)$. The Fe uptake capacities of $S$. molesta and $L$. gibba were not significantly different ( $>>0.05)$. In addition, the $\mathrm{BCF}$ values of the two plants for Fe were not significantly different $(\mathrm{p}>0.05)$ and the values were lower than 1000. The Fe removal efficiencies of S. molesta and L. gibba were $65.27 \%$ and $73.10 \%$ respectively. The efficiencies were not significantly different $(\mathrm{p}>0.05)$.

$\operatorname{Nickel}(\mathrm{Ni})$

The final Ni concentrations in both tanks were not significantly different ( $p>0.05)$. The Ni uptake capacities of S.molesta and L.gibba were not significantly different ( $p>0.05)$. The BCF values of the two plants for Ni were not significantly different $(\mathrm{p}>0.05)$ and the values were lower than 1000 .

Table 3: The mean values of initial Fe concentration in wastewater samples, final Fe concentration after being subjected to the treatment by plants, the metal uptake capacities of the two species and the Bio Concentration Factors (BCF).

\begin{tabular}{lcccc}
\hline Characteristic & $\begin{array}{c}\text { Control } \\
\text { Salvinia molesta }\end{array}$ & $\begin{array}{c}\text { Control } \\
\text { Lemna gibba }\end{array}$ & Salvinia molesta & Lemna gibba \\
\hline $\begin{array}{l}\text { Initial concentration } \\
\left(\mathrm{mg} \mathrm{l}^{-1}\right)\end{array}$ & - & - & $0.124 \pm 0.02^{\mathrm{A} 1}$ & $0.124 \pm 0.02^{\mathrm{A} 1}$ \\
$\begin{array}{l}\text { Final concentration } \\
\left(\mathrm{mg} \mathrm{l}^{-1}\right)\end{array}$ & - & - & $0.044 \pm 0.01^{\mathrm{B} 1}$ & $0.036 \pm 0.02^{\mathrm{B} 1}$ \\
$\begin{array}{l}\text { Metal uptake } \\
\text { capacity }\left(\mathrm{mg} \mathrm{kg}^{-1}\right)\end{array}$ & - & - & $4.008 \pm 1.79^{\mathrm{A} 2}$ & $4.408 \pm 1.74^{\mathrm{A} 2}$ \\
BCF & - & - & $652.7 \pm 53.71^{\mathrm{A} 3}$ & $731.0 \pm 120.16^{\mathrm{A} 3}$ \\
\hline
\end{tabular}

The significant differences are indicated by superscripted letters.

The Ni removal efficiencies of S. molesta and L. gibba were $66.39 \%$ and $61.87 \%$ respectively. The efficiencies were not significantly different $(\mathrm{p}>0.05)$.

Table 4: The mean values of initial Ni concentration in wastewater samples, final Ni concentration after being subjected to the treatment by plants, the metal uptake capacities of the two species and the Bio Concentration

\begin{tabular}{lcccc}
\hline Characteristic & $\begin{array}{c}\text { Control } \\
\text { Salvinia molesta }\end{array}$ & $\begin{array}{c}\text { Control } \\
\text { Lemna gibba }\end{array}$ & Salvinia molesta & Lemna gibba \\
\hline $\begin{array}{l}\text { Initial concentration } \\
\left(\mathrm{mg} \mathrm{l}^{-1}\right)\end{array}$ & - & - & $0.217 \pm 0.04^{\mathrm{A} 1}$ & $0.217 \pm 0.04^{\mathrm{A} 1}$ \\
$\begin{array}{l}\text { Final concentration } \\
\left(\mathrm{mg} \mathrm{l}^{-1}\right)\end{array}$ & - & - & $0.072 \pm 0.01^{\mathrm{B} 1}$ & $0.081 \pm 0.01^{\mathrm{B} 1}$ \\
$\begin{array}{l}\text { Metal uptake } \\
\text { capacity }\left(\mathrm{mg} \mathrm{kg}^{-1}\right)\end{array}$ & - & - & $7.258 \pm 1.79^{\mathrm{A} 2}$ & $6.783 \pm 1.74^{\mathrm{A} 2}$ \\
$\mathrm{BCF}$ & - & - & $663.9 \pm 69.63^{\mathrm{A} 3}$ & $618.7 \pm 51.32^{\mathrm{A} 3}$ \\
\hline
\end{tabular}
Factors (BCF).

The significant differences are indicated by superscripted letters.

$\operatorname{Lead}(\mathrm{Pb})$

The final $\mathrm{Pb}$ concentrations of the two tanks were not significantly different $(\mathrm{p}>0.05)$. The $\mathrm{Pb}$ uptake capacities of $S$. molesta and $L$. gibba were not significantly different ( $>0.05)$. The BCF values were lower than 1000 and the BCF value of $L$. gibba was significantly higher $(\mathrm{p}<0.05)$ than that of $S$. molesta. The $\mathrm{Pb}$ removal efficiencies of $S$. molesta and L. gibba were $74.85 \%$ and $85.74 \%$ respectively. The $\mathrm{Pb}$ removal efficiency by L. gibba was significantly higher $(\mathrm{p}<0.05)$ than that of $S$. molesta. 
Table 5: The mean values of initial $\mathrm{Pb}$ concentration in wastewater samples, final $\mathrm{Pb}$ concentration after being subjected to the treatment by plants, the metal uptake capacities of the two species and the Bio Concentration Factors (BCF).

\begin{tabular}{lcccc}
\hline & $\begin{array}{c}\text { Control } \\
\text { Salvinia molesta }\end{array}$ & $\begin{array}{c}\text { Control } \\
\text { Lemna gibba }\end{array}$ & Salvinia molesta & Lemna gibba \\
\hline $\begin{array}{l}\text { Initial concentration } \\
\left(\mathrm{mg} \mathrm{l}^{-1}\right)\end{array}$ & - & - & $0.292 \pm 0.07^{\mathrm{A} 1}$ & $0.292 \pm 0.07^{\mathrm{A} 1}$ \\
$\begin{array}{l}\text { Final concentration } \\
\left(\mathrm{mg} \mathrm{l}^{-1}\right)\end{array}$ & - & - & $0.073 \pm 0.02^{\mathrm{B} 1}$ & $0.043 \pm 0.01^{\mathrm{B} 1}$ \\
$\begin{array}{l}\text { Metal uptake } \\
\text { capacity }\left(\mathrm{mg} \mathrm{kg}^{-1}\right)\end{array}$ & - & - & $10.917 \pm 2.83^{\mathrm{A} 2}$ & $12.45 \pm 3.05^{\mathrm{A} 2}$ \\
BCF & - & - & $749.0 \pm 34.78^{\mathrm{B} 3}$ & $857.4 \pm 26.61^{\mathrm{A} 3}$ \\
\hline
\end{tabular}

The significant differences are indicated by superscripted letters.

According to Al-Khafaji et al. (2017) the $\mathrm{Cr}$, Ni and $\mathrm{Pb}$ removal efficiencies of Lemna minor are $32.26 \%, 74.48 \%$, and $79.1 \%$ respectively. However, in the present study, L.gibba has reported higher efficiencies for the removal of $\mathrm{Cr}$ and $\mathrm{Pb}$ and lower efficiency for the removal of $\mathrm{Ni}$. According to Verma and Suthar (2015), $\mathrm{Pb}$ removal efficiency of L.gibba at $\mathrm{pH} 7$ and $2 \mathrm{mg} \mathrm{l}^{-1} \mathrm{~Pb}$ concentrations is $93.8 \%$ which is higher than the present study. Dhir and Srivastava (2011) report $\mathrm{Cu}, \mathrm{Ni}$ and $\mathrm{Cr}$ removal efficiencies in a multi-metal solution by Salvinia natans respectively as $73.8 \%, 56.8 \%$, and $41.4 \%$. In the present study, S.molesta has shown higher efficiencies for the removal of $\mathrm{Ni}$ and $\mathrm{Cr}$ and lower efficiencies for the removal of $\mathrm{Cu}$.

\section{Bio Concentration Factor (BCF)}

Bio Concentration Factor $(\mathrm{BCF})$ is an index that provides information about the potential of the plants for the uptake of heavy metals. If the BCF value exceeds 1,000, the particular plant can be considered as a useful candidate for the uptake of heavy metals (Zayed et al. (1998). In the present study, none of the BCF values exceeded 1,000. According to Thayaparan et al. (2013), the BCF values of Azolla pinnata for $\mathrm{Pb}$ had increased with the increase in the initial $\mathrm{Pb}$ concentration and the $\mathrm{BCF}$ value is higher than 1,000 when the initial $\mathrm{Pb}$ concentration exceeds $4 \mathrm{mg} \mathrm{l}^{-1}$. Lokuge (2016) reports a reduction in BCFs of $\mathrm{Cr}, \mathrm{Cd}, \mathrm{Ni}$ and $\mathrm{Pb}$ when they were presented in altogether. According to the author, the competition of the metals for the uptake sites and the interactive effects of the metals are the reasons for the reduction of the $\mathrm{BCF}$ values.

According to Ranjitha et al. (2016), S. molesta has shown its potential in the uptake of $\mathrm{Cu}, \mathrm{Cr}, \mathrm{Pb}$ and $\mathrm{Cd}$ and any change in growth regulation is not observed. According to the observations of the present study also, S. molesta and L. gibba had grown healthily with the accumulation of these heavy metals. Toxicity symptoms caused by heavy metals were not observed in the harvested plant materials. However, the tolerance limits of the plants for the heavy metals are not discovered. Zayed et al. (1998) reports the $\mathrm{BCF}$ values of Duckweeds as 500 to 800 for $\mathrm{Cu}, 400$ to $700 \mathrm{for} \mathrm{Cr}$, and 50 to 450 for $\mathrm{Pb}$ at low supply concentrations $\left(1 \mathrm{mg} \mathrm{l}^{-1}\right)$. In the present study, similar BCF values are recorded for $\mathrm{Cu}$, but higher $\mathrm{BCF}$ values are recorded for $\mathrm{Pb}$ and $\mathrm{Cr}$.

\subsection{Plant material analysis}

The relative growth values of the two control samples were not significantly different ( $>>0.05)$. The relative growth values of $S$. molesta and $L$. gibba were significantly different $(\mathrm{p}<0.05)$. The relative growth value of $S$. molesta was the highest. The relative growth value of $L$. gibba was the second highest. The relative growth values of both control samples were lower than the $S$.molesta and L. gibba samples.

The dry weights of the two control samples were not significantly different $(p>0.05)$ and the dry weights of $S$. molesta and L. gibba were not significantly different ( $>>0.05$ ). The fresh weights of $S$. molesta and $L$. gibba were significantly different $(\mathrm{p}<0.05)$. The dry weights of the two control samples 
were not significantly different ( $\mathrm{p}>0.05)$. The final fresh weight of $S$. molesta plants was the highest because of its high moisture content. However, the dry weight of S. molesta was lower than the dry weight of L. gibba.

Table 6: The mean final fresh weights, mean relative growth values and the mean dry weights obtained from the tank with Salvinia molesta, the tank with Lemna gibba, the control tank with Salvinia molesta and the control tank with Lemna gibba.

\begin{tabular}{lcccc}
\hline & $\begin{array}{c}\text { Control } \\
\text { Salvinia molesta }\end{array}$ & $\begin{array}{c}\text { Control } \\
\text { Lemna gibba }\end{array}$ & Salvinia molesta & Lemna gibba \\
\hline Fresh weight $(\mathrm{g})$ & $17.828 \pm 2.16^{\mathrm{C} 1}$ & $16.479 \pm 1.37^{\mathrm{C} 1}$ & $34.918 \pm 3.67^{\mathrm{A} 1}$ & $24.197 \pm 3.67^{\mathrm{B} 1}$ \\
Relative growth & $1.188 \pm 0.14^{\mathrm{C} 2}$ & $1.099 \pm 0.09^{\mathrm{C} 2}$ & $2.191 \pm 0.37^{\mathrm{A} 2}$ & $1.613 \pm 0.24^{\mathrm{B} 2}$ \\
Dry weight $(\mathrm{g})$ & $0.536 \pm 0.20^{\mathrm{B} 3}$ & $0.543 \pm 0.12^{\mathrm{B} 3}$ & $1.091 \pm 0.19^{\mathrm{A} 3}$ & $1.135 \pm 0.35^{\mathrm{A} 3}$ \\
\hline
\end{tabular}

$\mathrm{n}=6$. The significant differences are indicated by superscripted letters.

In the control sample, distilled water was used as the substrate for the plant growth. At the end of the experiment, on the $7^{\text {th }}$ day, a brown coloration in leaves was observed in the control sample of $S$. molesta. But, S. molesta plants grown in the wastewater tank did not show a discoloration. The most likely reason for the brown colour observed in the control sample of $S$. molesta is the lack of nutrients.

However, in the control sample of L. gibba, no discoloration was observed. The L. gibba plants showed an increase in growth even in the control sample as well as in the wastewater sample. Therefore, the potential of $L$. gibba species to survive in adverse conditions can be identified.

According to Zayed et al. (1998), growth reduction of Duckweeds is reported only at $10 \mathrm{mg} \mathrm{l}^{-1} \mathrm{Ni}$ concentration. Also, Ranjitha et al. (2016) reports that there is no change in the growth rate of $S$. molesta when exposed to $\mathrm{Cr}, \mathrm{Cu}, \mathrm{Cd}$ and $\mathrm{Pb}$ containing wastewater where the particular heavy metals were present in concentrations lower than $2.5 \mathrm{mg} \mathrm{l}^{-1}$. Therefore in the present study, the low concentration of heavy metals may be the reason for the absence of growth reduction in the plants grown in wastewater tanks.

Srivastav et al. (1994) report the relative growth values of Salvinia spp. at $1 \mathrm{ppm}$ of $\mathrm{Cr}$ concentration as 1.15 and at $1 \mathrm{ppm} \mathrm{Ni}$ concentration as 1.17. Also he reports the relative growth values of Spirodela spp. at $1 \mathrm{ppm}$ of $\mathrm{Cr}$ concentration and at $1 \mathrm{ppm}$ Ni concentration respectively as 1.16 and 1.13. In the present study, $S$. molesta and L. gibba plants grown in wastewater and control sample of $S$. molesta recorded greater relative growth values. The most likely reason is the low concentrations of heavy metals in wastewater. Only $\mathrm{Cr}$ was present in a concentration higher than $1 \mathrm{ppm}$ in the wastewater used in the present study. The moisture content of fresh $S$. molesta may be the reason for the high relative growth value in control sample.

\section{Discussion}

According to the obtained results, S. molesta and L. gibba have proven their potential for the removal of nutrients and heavy metals from municipal wastewater. S. molesta has performed well in the removal of Total Nitrogen, Phosphates, BOD and COD reporting the removal efficiencies respectively as $73.35 \%, 72.63 \%, 71.51 \%$ and $61.98 \%$. Also, L. gibba demonstrated a significant removal of Total Nitrogen, Phosphates, BOD and COD reporting the removal efficiencies respectively as $62.18 \%, 77.28 \%$, $67.24 \%$ and $78.96 \%$. S. molesta was more efficient in the removal of Total Nitrogen and L. gibba showed a greater removal efficiency for COD.

The average $\mathrm{Cr}, \mathrm{Cu}, \mathrm{Fe}, \mathrm{Ni}$ and $\mathrm{Pb}$ removal efficiencies of $\mathrm{S}$. molesta were $81.66 \%, 69.81 \%$, $65.26 \%, 66.39 \%$ and $74.85 \%$ respectively. The average $\mathrm{Cr}, \mathrm{Cu}, \mathrm{Fe}, \mathrm{Ni}$ and $\mathrm{Pb}$ removal efficiencies shown by $L$. gibba were $86.99 \%, 69.77 \%, 73.10 \%, 61.87 \%$ and $85.74 \%$ respectively. L. gibba performed greater removal efficiencies in the removal of $\mathrm{Cr}$ and $\mathrm{Pb}$ when compared to $\mathrm{S}$. molesta. But, the Bio 
Concentration Factors recorded by $S$. molesta and L. gibba in the uptake of selected heavy metals were always lower than 1000 in the present study. Visual toxicity symptoms were not observed in the plant materials grown in the wastewater tanks. However, both S. molesta and L. gibba can be considered as suitable candidates for the removal of nutrients and these heavy metals $(\mathrm{Cr}, \mathrm{Cu}, \mathrm{Fe}, \mathrm{Ni}$ and $\mathrm{Pb})$ from wastewater even at low heavy metal concentrations.

\section{Conclusion}

This study was carried out to investigate the nutrient and heavy metal removal potential and the efficiencies of $S$. molesta and L. gibba for the removal of nutrients and selected heavy metals $(\mathrm{Cr}, \mathrm{Cu}, \mathrm{Fe}$, $\mathrm{Ni}$ and $\mathrm{Pb}$ ) from municipal wastewater samples collected from the influent of Moratuwa-Ratmalana wastewater treatment plant.

These aquatic plants have the potential of phytoaccumulation of nutrients and heavy metals from water. This strategy is a low cost and eco-friendly technology for the treatment of wastewater. The invasive nature of $S$. molesta and the fast growth rate of $L$. gibba are the practical issues that may arise in the practical use of these plants.

\section{References}

Ali, H., Khan, E. and Sajad, M.A., 2013. Phytoremediation of heavy metals-concepts and applications. Chemosphere, 91:869-881.

Al-Khafaji, M.S., Al-Ani, F.H. and Ibrahim, A.F., 2017. Removal of some heavy metals from industrial wastewater by Lemna minor. KSCE Journal of Civil Engineering, 1-6.

Danushika, U.A.A.G., Bandara N.J.G.J., and Rupasinghe S.K.L.S., "Performance assessment of Moratuwa-Ratmalana biological nutrient removal industrial wastewater treatment plant." Proceedings of International Forestry and Environment Symposium, 21. 2017.

Dhir, B. and Srivastava, S., 2011. Heavy metal removal from a multi-metal solution and wastewater by Salvinia natans. Ecological Engineering, 37:893-896.

Kalagbor, I.A. and Opusunju, K., 2015. A comparison study of dry and wet ashing methods used for the assessment of concentration of five heavy metals in three vegetables from Rivers State, International Journal of Environmental Research and Public Health, 2:16-22.

Körner, S. and Vermaat, J.E., 1998. The relative importance of Lemna gibba L., bacteria and algae for the nitrogen and phosphorus removal in duckweed-covered domestic wastewater. Water Research, 32:3651-3661.

Koutika, L.S. and Rainey, H.J., 2015. A review of the invasive, biological and beneficial characteristics of aquatic species Eichhornia crassipes and Salvinia molesta. Applied Ecology and Environmental Research, 13:263-275.

Kumari, M. and Tripathi, B.D., 2014. Effect of aeration and mixed culture of Eichhornia crassipes and Salvinia natans on removal of wastewater pollutants. Ecological Engineering, 62:48-53.

Lokuge, U.M.L., 2016. A study on the Phytoremediation Potential of Azolla pinnata under laboratory conditions. Journal of Tropical Forestry and Environment, 6.

Mkandawire, M. and Dudel, E.G., 2005. Accumulation of arsenic in Lemna gibba L. (duckweed) in tailing waters of two abandoned uranium mining sites in Saxony, Germany. Science of the Total Environment, 336:81-89.

Mohedano, R.A., Costa, R.H., Tavares, F.A. and Belli Filho, P., 2012. High nutrient removal rate from swine wastes and protein biomass production by full-scale duckweed ponds. Bioresource Technology, 112:98-104.

Ng, Y.S. and Chan, D.J.C., 2017. Wastewater phytoremediation by Salvinia molesta. Journal of Water Process Engineering, 15:107-115.

Journal of Hazardous Materials Ranjitha, J., Raj, A., Kashyap, R., Vijayalakshmi, S. and Donatus, M., 2016. Removal of heavy metals from Industrial Effluent using Salvinia molesta. International Journal of ChemTech Research, 9: 608-613. 
Srivastav, R.K., Gupta, S.K., Nigam, K.D.P. and Vasudevan, P., 1994. Treatment of chromium and nickel in wastewater by using aquatic plants. Water Research, 28:1631-1638.

Thayaparan, M., Iqbal, S.S., Chathuranga, P.K.D. and Iqbal, M.C.M., 2013. Rhizofiltration of Pb by Azolla pinnata. International Journal of Environmental Sciences, 3:1811.

Uysal, Y., 2013. Removal of chromium ions from wastewater by duckweed, Lemna minor L. by using a pilot system with continuous flow, 263:486-492.

Verma, R. and Suthar, S., 2015. Lead and cadmium removal from water using duckweed-Lemna gibba L.: Impact of $\mathrm{pH}$ and initial metal load. Alexandria Engineering Journal, 54:1297-1304.

Zaltauskaite, J., Sujetoviene, G., Cypaite, A. and Auzbikaviciute, A., 2014, January. Lemna minor as a tool for wastewater toxicity assessment and pollutants removal agent. In Environmental Engineering. Proceedings of the International Conference on Environmental Engineering. ICEE. 9, p. 1. Vilnius Gediminas Technical University, Department of Construction Economics and Property.

Zayed, A., Gowthaman, S. and Terry, N., 1998. Phytoaccumulation of trace elements by wetland plants: I. Duckweed. Journal of Environmental Quality, 27:715-721. 